\title{
Correlation of military expenditures and economic growth: lessons for Romania
}

\author{
Oana Ramona Lobont ${ }^{1} \cdot$ Oana Ramona Glont ${ }^{2} \cdot$ Leonardo Badea $^{3} \cdot$ Sorana Vatavu $^{1}$
}

Published online: 3 July 2019

(c) The Author(s) 2019

\begin{abstract}
This paper examines the correlation between public policies in the field of military expenditures and economic growth in Romania. The research is built upon the vast literature focused on the field of public policies and economic growth. Whereas economic growth became one of the most dynamic areas in economics, this correlation will consider the determinants of the real sector development through economic phenomenon modeling. The impact of military expenditures on growth is analysed for Romania, using annual data over the period 1991-2016. The research methodology employed is the Granger causality test. The empirical results reveal that there is a bidirectional relationship between military expenditure and GDP over the long run, with a positive effect described by both relationships through several models exemplified in the analysis. From the economic point of view, these results highlight the impact of military expenditures, generating different positive effects on labor, capital, economic growth and efficient use of resources in the economic sector, at the national level.
\end{abstract}

Keywords Military expenditures $\cdot$ Economic growth $\cdot$ Granger causality test $\cdot$ Romania

Oana Ramona Glont

oanaramona.glont@gmail.com

Oana Ramona Lobont

oana.lobont@e-uvt.ro

Leonardo Badea

leobadea@yahoo.com

Sorana Vatavu

sorana.vatavu@e-uvt.ro

1 Finance Department, Faculty of Economics and Business Administration, West University of Timisoara, Street V. Parvan, No. 4, 300223 Timisoara, Timis, Romania

2 Doctoral School of Economics and Business Administration, West University of Timisoara Romania, Street V. Parvan, No. 4, 300223 Timisoara, Timis, Romania

3 Faculty of Economic Sciences of Valahia, University of Târgovişte Valahia, Bd. Carol I, No. 2, 130024 Targoviste, Dambovita, Romania 


\section{Introduction}

This paper highlights the correlation between military expenditures and economic growth in Romania, based on specific indicators (military expenditures and GDP per capita) considered over a period of 26 years (1991-2016). This relationship is relevant for decisionmakers as it also impacts other macroeconomic indicators, such as economic development and productivity, unemployment, investments, or other variables reflecting the well-being of the society, as well as the monetary system, mostly through interest rates. The latter is mainly influenced by the import of weapons, equipment acquisitions and other operations in the field of defense and security.

Military expenditures are an important part of a country's national budget. From the economic point of view, military expenditures are part of the government spending for national defense, determined by national fiscal policies. Generally, in terms of the countries' defense, the communities have small but well-equipped units with a high capacity of reaction, being relatively evenly dispersed within the NATO territory. In the military and security field, there is a strong emphasis on the issues of mobility and capacity to displace contingents, coupled with a well-established military intelligence system.

Considering that special telecommunication and everything related to it (equipment, software, fixed and mobile telecommunication units, radio countermeasures, etc.) represents one of the basic pillars of Western defense, we can conclude that the defense budget and implicitly the military expenditures have a decisive impact on the economic growth of Romania, while the correlation between military expenditure and GDP is a categorical one.

Vectors for financing direct investments, which cannot be undertaken by the private sector, define the stimulation of real economic development. Therefore, it is important to consider an interdisciplinary approach because it involves identifying interdependencies that capture the most important interactions between growth, factors of production, income distribution, demographics, culture, political and macroeconomic stability, and government policies. Recent empirical research highlights the fact that the structure of budget expenditures provides an eloquent framework for state intervention in the stimulation of the development process of the real sector (Brasoveanu and Brasoveanu 2007).

The relevance of the budgetary expenditure structure in explaining the economic growth was also explained by Barro and Sala-i-Martin (1995) in its empirical studies, using the regression method, with exact reference to health expenditures, education, capital budget expenditures, defense. After dividing budget expenditures into three categories: productive, unproductive and others, Barro and Sala-i-Martin (1995) concluded that the first category positively influences economic growth, while nonproductive and other types are a brake on the economy.

The paper presents a review of the literature on the relationship between military expenditures and economic growth, followed by Sect. 3, describing the data and the methodology the Granger causality. The results are highlighted and explained in Sect. 4, and the last section concludes. 


\section{The relationship between military expenditures and economic growth}

From the economic point of view, military expenditures represent an instrument for public policies with a multiplied effect on real economy. More specifically, these expenditures can help create social infrastructure and other forms of public goods. The recent research underlines that, according to their functional classification, the structure of military expenditures provides a closer description of how the state intervention may stimulate the development process of the real sector. Furthermore, this could reveal more details on the specific influence on growth, compared to the general level of budget expenditures.

Economic studies focused on the impact of military industry on economic growth frequently explain the evolution of GDP or GDP growth rate based on a set of exogenous factors, estimating the regression coefficients of these factors, and specifying their intensity and statistical significance with reference to their influence on the economic growth process.

The classification of budget expenditures in three major categories allows the separate analysis of each one, and their influence on economic growth at the intuitive level. The first category generates the stimulation of real activity, while the other two induce turning points in economic development. The insignificant effects of budget expenditures on economic growth can also be explained by the fact that the global value of expenditures is considered to be an exponential variable, and their structure-education expenditures, health expenditures, capital budget expenditures, military expenses-is more relevant in explaining economic growth.

Over the time, the relationship between the military sector and economic growth has been described base on several schools of thought. Keynesians particularly argue that military expenditures may be increased to stimulate or diminish demand, being an important instrument for fiscal policy. This idea mainly considers that military spending has positive effects on the economy. On the contrary to the Keynesians point of view, another school of thought considers the negative effects of military expenditures, if applied as a fiscal policy instrument. In this case, the argument presumes that resources used in the army would yield more if they were allocated for other areas. This assumption proved to be relevant for the least developed countries (Jingxi et al. 2015).

Over time, several findings on the correlation between defense spending and economic growth were described by specialists, taking into account various variables such as military spending and level of economic development (income), military spending and GDP, military expenditures and employment (unemployment). These findings led to policy analysis useful for by state officials and decision-makers at the level of fiscal policy, budget allocation and their impact on economic well-being.

Cappelen et al. (1984) described the impact of military spending on investment based on data for 17 OECD countries, over the period 1960-1980. Results indicated a negative influence on economic growth for the entire sample, except for Mediterranean countries. However, more recent studies analysing extended samples of countries, highlight a direct relationship between the variables (Korkmaz 2015). For example, Chang et al. (2011) applied the GMM method to a panel data comprising 90 countries, with data from 1992 to 2006. Their results proved that military spending actually induces economic growth in low-income countries. Moreover, this direct relationship between military spending and economic growth was specific to European countries and also to the Middle East and South Asia. 
Wijeweera and Webb (2011) employed co-integration in a panel of five developing countries in South Asia, over the period 1988-2007. Results indicated that 1\% increase in military spending induces a very low increase in real GDP $(0.04 \%)$. Therefore, the influence of military spending on economic growth is neglectable in these countries. Pradhan et al. (2013) also implemented cointegration through a dynamic multivariate system, analysing 22 countries over the period 1988-2012. They found a balanced relationship between military spending and economic growth.

Yakovlev (2007) also indicated that an increase in military spending and separate arms exports could negatively influence the economic growth, but overall, higher military spending is less influential on the economy if the country is exporting arms. The results of the study indicate that all variables in the analysed models are statistically significant at a percentage. More specifically, while public spending is positively linked to economic growth, GDP has a negative influence. Surprisingly, real military spending and interest rates have a negative impact on economic growth. It was also found that the military burden in the U.S. has a negative impact on economic growth as a share of GDP, and as a result, there is an increase in military service issues, which could indeed have led to low economic growth in the US (Khalid et al. 2015). Empirical tests indicate that military spending has negative consequences on the development of the economy by reducing productive capital investments.

Rota (2015) proposes a research debating the role of democratisation on military spending, which was taken into account by querying the data collected on a sample of 20 countries, observed between 1880 and 1938, for political structure, governance, and other risk factors. Considering democracy as a product of several elements, Rota underlines that it is crucial to identify the factors determining effective democratisation. The argument, supported by the data, is that the formal rules that constrain the directors, who have often been the first rudiments of the evolution of a democracy, have a small role in explaining the Kantian effect. But after the executive constraints came, as a rule, the effective public participation. All of these play an essential role in reducing military spending, concluding that democracy, government policy in a state, and liberalisation have an important role in redistributing budgets and allocating state resources.

Pan et al. (2014) reviewed the causal relationship between military spending and economic growth in Middle Eastern countries. Their results reflect different causality effects: a unidirectional causality in Turkey's military spending, a unilateral causal effect between economic growth and military spending for Egypt, Kuwait, Lebanon and Syria, two-way causal influence in Israel, and no causality effect for Jordan, Oman and Saudi Arabia. Another study on causal relationships between military expenditures and the economy was realized by Chang et al. (2014) in China and the G7 countries for the period 1988-2010. Their empirical results indicated that military spending has a positive effect on growth for Canada and the UK, while for China the data demonstrated the opposite effect, from economic growth towards military spending. More recently, the analysis for China revealed the same positive causality from growth to defense expenditure over the short-term, and a bidirectional causality between economic growth and defense expenditure over the longrun, with an ambiguous effect of defense expenditures on economy (Su et al. 2018).

The causality relationship also exists in terms of the influence of military expenditure on the unemployment rate. This conclusion is largely related to middle-income and lowincome countries or countries that are not OECD members. Studies revealed that on one hand, defense spending positively influences the long-term employment situation in the EU countries, but, on the other hand, it has a negative effect on the short-term workforce (Huang and Kao 2005). 
The policies nowadays focus on an increase in the training and education of military personnel in defense and security capabilities. According to the country's defense strategy in 2015-2019, and due to the fact that the military risks increased considerably, it was envisaged for Romania to secure its military base by allocating $2 \%$ of GDP in 2017, more than previously. All of these costs are reported directly to the country's GDP.

An enemy, first from a strategic and economic, then a military point of view, can be identified in the European Union at this moment in the context of the binomial NATO-US. Most geopolitical analysts-both Euro-Atlantic and Eurasian — have reported the military dimension of the deep Eastern-Western interaction, but conclude that the existing problems lie in all areas, economic, social and, above all, religious (Huntington 2007). The open sources available at this moment point to the fact that we are likely to witness military conflicts in the near future. This emphasizes the need to strengthen military capabilities, strategic partnerships and co-operate with other NATO member states, especially those in the Eastern flank. Considering these, Romania should be armed and, in the near future, in the need of militarization and rearmament (Drăghici 2016). Based on all these aspects, Romania plans an increase in military expenditures in the following years, reaching $2 \%$ of GDP in 2017, with an absolute amount of the defense budget of 3.6 billion EURO, as well as in Lithuania and Latvia, where large increases in defense budgets were recorded by $0.2 \%$ and $0.3 \%$ of GDP compared to previous years (Economica.net 2017).

In every country, national defense is an important component of the national security and security strategy and, at the same time, it expresses the content of the state's external function. Resources allocated yearly to this sector serve the maintenance and functioning of national armies, participation in various military alliances, maintenance of military bases in foreign territories, military aid to other countries. We can conclude that military expenditures represent the public expenditures allocated within a separate budget, the Ministry of Defense budget, distributed on several categories. First of all, there are expenditures for the maintenance of the armed forces in the country or within the military bases of other countries. These are materialized in the procurement of goods and services, as well as an endowment with equipment, weaponry, and fighting techniques. Besides these, there are other military expenditures, financed by special funds separated from the state budget, or military "civil" expenditures included in the budgets of other ministries.

In view of the above, military expenditure involves important human, material and financial resources for the maintenance and training of military personnel, services related to national defense. Moreover, according to the specialists in the field, the criterion of spending on military development currently accounts for $20-25 \%$ of the defense budget (Eurostat 2017). The allocation of a special budget within the Ministry of Defense leads us to the conclusion that there should be clear and definite effects on the development of the economy. Whether or not there is a relationship between military spending and economic growth in Romania will be reflected through the Granger causality test.

Considering two decades in 1990-2011, in Romania, Brasoveanu and Brasoveanu (2007) discovered that a percentage point of the share of budget expenditures in GDP generates a 1.58 percentage point decrease in the real GDP growth rate. However, results are different when the categories of public expenditures are grouped according to their theoretical impact on the real economy, respectively in productive expenditures (general public services, defense, security, public policy and national security, education, health, public services and development, housing, environment and water, transport and communications), non-productive (culture, recreation, religion, insurance and social assistance, industry, agriculture, silviculture, fishing, other actions economic) and other expenses, other shares, interest banking (Barro and Sala-i-Martin1995). The correlation coefficients 
between these three expenditure categories and the real GDP growth rate imply a positive causal link between productive spending and economic growth, a negative correlation between unproductive spending and economic growth, and a positive causal link between other expenditures and GDP growth. Estimating the effects of budget challenges on economic growth does not reflect all aspects of the problem, it can not isolate the consequences of budgetary policy towards the way these are financed through taxes or by covering the deficit through public debt issues.

Jingxi et al. (2015) also studied the relationship between military spending and economic growth and the conclusion is that there is no consistent pattern for all countries. For the majority of the states analysed, the most powerful predictor of the current military expenditures is the level of military expenditures in the past, regardless of whether these expenses are measured in levels or as part of production.

The results indicated that there is evidence of a strong relationship between military spending in five states of the world (USA, Russia, Japan, India, China). According to the statistics, economic growth in these five countries will push an increase in military spending and their military capabilities. However, we conclude that each country is unique and strong economic growth does not automatically involve expanding military spending or capabilities.

This paper contributes to the existing literature through the analysis on a recent dataset, over the period 1991-2016, and results from various correlations between military expenditures and economic growth in Romania. Although previous studies analysed these aspects, this research highlights the differences between the development stage of the countries, the periods and variables considered. For this reason, studying the impact of military expenditures on economic growth in Romania (taking into account GDP growth rate and GDP per capita), over a period of 26 years, through Granger causality analysis, reveals an effect over the long run, observed in a bidirectional relationship and confirmed based on multiple causal models.

\section{Data and methodology}

As previously discussed, from the broad literature on the relationship between economic growth and military expenditures, findings are often contradictory and inconclusive. Alptekin and Levine (2012) implemented a meta-analysis based on 32 studies employing 169 estimates in order to observe the combined influence of military expenditures on economic growth. The results reveal the positive effect military expenditures have on economic well-being. In addition, Awawor and Yew (2014) suggest that estimating the magnitude of the effect is strongly influenced by variations in the study. Particularly, econometric specifications, as well as the type of data and the periods considered, are relevant factors that explain heterogeneity in the literature focused on military spending growth. The results proving that military expenditures have a positive impact on growth are more pronounced in developed and less developed countries. This confirms the hypothesis of a non-linear relationship between military expenditures and growth, as literature findings are often contradictory and inconclusive.

The data analysed in this research refers to military expenditures and GDP in Romania, over the period 1991-2016. In order to test the relationship between the two indicators, three variables were considered for each one. Therefore, three different models with 
corresponding results will be presented in comparison, to check for the robustness of the analysis. The military expenditures were expressed by the:

- military expenditures as percentage of GDP (mexpingdp);

- natural logarithm of military expenditures expressed in local currency-lei (lmexp);

- annual growth of military expenditures per capita in USD (mexppercapgrusd).

The GDP variables comprised in the models were:

- annual growth of GDP (gdpgr);

- annual growth of GDP per capita in local currency-lei (gdppercapgr);

- annual growth of GDP per capita in USD (gdppercapgrusd).

The relationships between military expenditures (mexp) and GDP in Romania were tested through Granger causality, with simple two-variable models. All the variables considered were stationary time series. The simple causal model in this case, as expressed by Granger (1969), would have the following form:

$$
\begin{aligned}
& G D P_{t}=\sum_{j=1}^{m} a_{j} G D P_{t-j}+\sum_{j=1}^{m} b_{j} m \exp _{t-j}+\varepsilon_{t} \\
& \operatorname{mexp}_{t}=\sum_{j=1}^{m} c_{j} G D P_{t-j}+\sum_{j=1}^{m} d_{j} \operatorname{mexp} p_{t-j}+\eta_{t}
\end{aligned}
$$

where $m=26$ as there are 26 years in the period analysed (1991-2016), $\varepsilon_{t}$ and $\eta_{t}$ are non

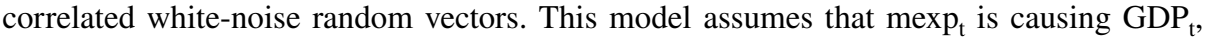
provided some $b_{j}$ is not zero. Similarly, $\mathrm{GDP}_{\mathrm{t}}$ is causing $\operatorname{mexp}_{\mathrm{t}}$, if some $c_{j}$ is not zero. If these events occur simultaneously, there is a feedback relationship between military expenditures $\left(\operatorname{mexp}_{t}\right)$ and GDP $\left(\mathrm{GDP}_{\mathrm{t}}\right)$.

After estimating the Granger cause analysis results, lag-order selection statistics will be employed to acknowledge, through the sequence of likelihood ratio (LR) and different information criteria (Akaike's information criterion-AIC; Hannan and Quinn information criterion-HQIC; Schwarz's Bayesian information criterion -SBIC), the optimal lag indicated by "**" for each of the three models.

\section{Research results and discussion}

The first model considers the Granger causality between the military expenditures expressed as percentage in GDP and the annual growth of GDP. The results of the Granger analysis and selection order criteria are included in Table 1.

For the first four lags we fail to reject the null hypothesis as results indicate that, although the Chi-squared reflects a positive relationship, military expenditures do not granger cause GDP growth. However, from lag five, this military expenditures indicator indicates a statistically significant positive effect on GDP growth. For higher lags the effect gradually increases, while the highest granger-cause is observed for lag eight. 
Table 1 Results of Granger-Causality tests between military expenditures as percentage of GDP (mexpingdp) and annual growth of GDP (gdpgr)

\begin{tabular}{|c|c|c|c|c|c|c|c|}
\hline \multirow[t]{2}{*}{ lag } & \multirow{2}{*}{$\begin{array}{l}\text { Response vari- } \\
\text { able (gdpgr) } \\
\text { Chi-squared }\end{array}$} & \multirow{2}{*}{$\begin{array}{l}\text { Response variable } \\
\text { (mexpingdp) } \\
\text { Chi-squared }\end{array}$} & \multicolumn{5}{|c|}{ Selection-order criteria } \\
\hline & & & LR & $p$ value & AIC & HQIC & SBIC \\
\hline 1 & 0.0004 & 0.406 & 64.45 & 0.000 & -5.374 & -5.333 & -5.077 \\
\hline 2 & 0.248 & 2.372 & 2.779 & 0.595 & -5.084 & -5.016 & -4.589 \\
\hline 3 & 0.286 & 2.266 & 6.377 & 0.173 & -4.994 & -4.898 & -4.302 \\
\hline 4 & 0.260 & 4.506 & 5.602 & 0.231 & -4.861 & -4.738 & -3.970 \\
\hline 5 & 12.341 & $19.505^{* * *}$ & 4.525 & 0.340 & -4.668 & -4.518 & -3.579 \\
\hline 6 & $18.689 * * *$ & $19.499 * * *$ & 9.677 & 0.046 & -4.761 & -4.584 & -3.475 \\
\hline 7 & $17.217 * *$ & $140.41 * * *$ & $66.256^{*}$ & 0.000 & $-7.998 *$ & $-7.793 *$ & $-6.514^{*}$ \\
\hline 8 & $71.26^{* * * *}$ & $280.91 * * *$ & & & & & \\
\hline
\end{tabular}

For Chi-squared $* * *, * *, *$ is statistically significant at $1 \%, 5 \%, 10 \%$ level

The lag-order selection statistics prove that more lags would return better results over the period analysed, more specifically, the seventh lag would be the most appropriate.

The first model results indicate that there is bidirectional causal relationship between the variables considered. On one hand, the military expenditures (as percentage in GDP) granger cause the annual growth in GDP. On the other hand, results also prove that the annual growth in GDP granger causes the military expenditures. Both are direct causes, and the second seems stronger based on the Chi-squared results. The difference in the Chi-squared levels indicate that the relationship (granger cause) from the annual growth of GDP variable towards the military expenditures is more powerful, which may be due to the fact that the expenditures are assessed as percentage in GDP.

The second model represents the Granger causality between the annual amount (in lei) of the military expenditures and GDP per capita (in lei). Results are similar to the ones described through the first model and presented in Table 2.

Table 2 Results of Granger-Causality Tests between military expenditures expressed in lei (lmexp) and annual growth of GDP per capita in lei (gdppercapgr)

\begin{tabular}{lllrlrll}
\hline lag & $\begin{array}{l}\text { Response variable } \\
\text { (gdppercapgr) } \\
\text { Chi-squared }\end{array}$ & $\begin{array}{l}\text { Response vari- } \\
\text { able (lmexp) } \\
\text { Chi-squared }\end{array}$ & \multicolumn{1}{l}{ LR } & $p$ value & AIC & HQIC & SBIC \\
\cline { 5 - 8 } & 0.349 & 0.505 & 85.861 & 0.000 & 3.097 & 3.139 & 3.395 \\
2 & 0.339 & 0.013 & 5.549 & 0.235 & 3.234 & 3.302 & 3.728 \\
3 & 3.708 & 0.807 & 2.716 & 0.606 & 3.527 & 3.623 & 4.22 \\
4 & 5.131 & 1.124 & 5.295 & 0.258 & 3.677 & 3.800 & 4.568 \\
5 & $11.632^{* *}$ & 1.691 & 12.415 & 0.015 & 3.432 & 3.582 & 4.521 \\
6 & $11.233^{*}$ & $33.212^{* * *}$ & 8.954 & 0.062 & 3.379 & 3.557 & 4.665 \\
7 & $12.83^{*}$ & $24.556^{* * *}$ & 14.821 & 0.005 & 3.001 & 3.205 & 4.484 \\
8 & $145.95^{* * *}$ & $81.14^{* * *}$ & $672.92^{*}$ & 0.000 & $-33.94 *$ & $-33.71 *$ & $-32.26 *$ \\
\hline
\end{tabular}

For Chi-squared $* * *, * *, *$ is statistically significant at $1 \%, 5 \%, 10 \%$ level 
Although the first four lags of the variables do not prove a significant causal relationship, from lag five, military expenditures granger cause the growth in GDP per capita. Moreover, from lag six the model indicates a bidirectional causal relationship, as GDP per capita also granger causes the level of military expenditures. The model reflected by lag eight is the best in terms of statistical significance, as the probability of Chi-squared is significant at $1 \%$ level.

This was also proved by the lag-order selection statistics suggesting that lag eight is the most appropriate for the model considered. Again, a bidirectional relationship between military expenditures and GDP was proven: higher military expenditures granger cause an increase in the GDP per capita, and the GDP per capita granger causes the level of military expenditures. However, from the eight lag model, the Chi-squared indicates a stronger granger cause from the level of military expenditures to GDP per capita.

The third model is based on the relationship between the military expenditures per capita and the annual growth in GDP per capita. Its results are presented in Table 3.

In this case, the indicators consider the values in USD. Up to lag five, results present a direct relationship between the variables, which is not statistically significant. However, the results of the six lag model highlight that GDP per capita is a granger cause for the military expenditures (significant at 5\% level). By adding more lags, results indicate a statistically significant bidirectional relationship, as military expenditures per capita are also a granger cause for the growth in GDP per capita. According to the lag-order selection statistics, lag six is the most appropriate for this model, and the growth in GDP per capita seems to be a stronger granger cause for the growth in military expenditures per capita.

Granger causality analysis indicates that, over the long term, there is a bidirectional relationship between military expenditures and GDP, with a positive effect described by both relationships in all the models considered. This confirms the results robustness.

In the first decade of the period analysed, the military expenditures were, on average, $3.1 \%$ of the GDP, but after 2010 the average percentage decreased to $1.3 \%$. In January 2015, following NATO and US claims that its allies have increased their defense budgets, Romania has decided to allocate 2\% of its GDP or Armed Forces starting from 2017 and to maintain it within the next ten years.

Table 3 Results of Granger-Causality Tests between annual growth of military expenditures per capita in USD (mexppercapgrusd) and annual growth of GDP per capita in USD (gdppercapgrusd)

\begin{tabular}{lllllllll}
\hline lag & $\begin{array}{l}\text { Response variable } \\
\text { (gdppercapgrusd) } \\
\text { Chi-squared }\end{array}$ & $\begin{array}{l}\text { Response variable } \\
\text { (mexpercapgrusd) } \\
\text { Chi-squared }\end{array}$ & \multicolumn{2}{l}{ Selection-order criteria } \\
\cline { 5 - 8 } & LR & $p$ value & AIC & HQIC & SBIC \\
\hline 1 & 0.005 & 1.113 & 8.966 & 0.062 & 15.233 & 15.274 & 15.53 \\
2 & 1.378 & 3.919 & 3.032 & 0.552 & 15.509 & 15.577 & 16.004 \\
3 & 1.458 & 2.22 & 0.968 & 0.915 & 15.9 & 15.995 & 16.592 \\
4 & 1.037 & 1.504 & 9.742 & 0.045 & 15.803 & 15.926 & 16.693 \\
5 & 0.977 & 2.24 & 4.281 & 0.369 & 16.009 & 16.159 & 17.098 \\
6 & 2.646 & $12.33^{*}$ & $33.997^{*}$ & 0.000 & $14.565^{*}$ & $14.743^{*}$ & $15.852^{*}$ \\
7 & $12.23^{*}$ & $26.853^{* * *}$ & 0.786 & 0.940 & 14.966 & 15.171 & 16.45 \\
8 & $24.196^{* * *}$ & $40.963^{* * *}$ & & & & & \\
\hline
\end{tabular}

For Chi-squared $* * *, * *, *$ is statistically significant at $1 \%, 5 \%, 10 \%$ level 
On May 11, 2017, the Romanian Parliament approved an expenditure program of 9.3 billion euros ( $\$ 10.5$ billion) for the 2017-2026 decade, which includes eight major programs: short distance defense systems and defense systems short-term control systems, control systems, infantry fighting vehicles, armored carriers, long-range rocket systems and long-range missile systems. Other programs will be subject to parliamentary approval in the near future, such as the acquisition of attack and transport helicopters.

For Romania, allocating and spending $2 \%$ of GDP is both a strategic target and a diplomatic tool. Participation in NATO's “Two-Percent Club" gives Romania some sdiplomatic influence within the organisation. Increasing defense spending, in full agreement with economic growth, is a certainty of NATO's larger presence along the Eastern Bloc.

Romania has chosen a measured path, gradually increasing expenditures over the period 2015-2017 to reduce budget deficits and maintain economic growth. Between 2015 and 2017, there has been a steady increase in defense spending, with the structure of the defense budget being modified so that in 2016, $29 \%$ of the budget was used to purchase new equipment, while in the current budget approximately $45 \%$ was allocated to investment and acquisitions.

\section{Conclusion}

In this paper, it was considered the dynamic link and causal relationship between military expenditures and economic growth in Romania, using the Granger-Causality tests. Two important reasons justify this approach, namely the geostrategic and geopolitical importance of Romania and the modernization of Romania's military potential.

Taking into account the geopolitical situation of the area, Romania must overcome almost a decade of sub-investment in the military, which implies the need for military modernization in general. Romania's policy needs to be adapted to sustain a sustained defense force in the future so that the economy can benefit from increased defense spending through lucrative offsets for the local military industry.

Theoretical insights from the literature indicate that, in the context of economic growth, military expenditures were analysed from different aspects. Although the association between the two was clear in many studies, a significant part of the research leads to contrary results across countries, inconsistent over different time periods.

For Romania, this research proves that economic growth is a cause of the increase in military expenditures over the long-term (a period higher than six years). Moreover, as the period extends (eight years or more), the military expenditures become an important cause for the economic growth reflected through GDP. These conclusions follow the main idea obtained by analysing the correlation between the three expenditure categories (productive, non-productive and other expenditures) and the real GDP growth rate, implying that there is a positive causal link between productive spending (where military expenditures are included) and economic growth.

These findings ensure the continuation of the national policies, the national security objectives of Romania materialized by ensuring the efficiency of the national systems for prevention and management of crisis situations, internal and external, military or civilian. Faced with the great regional and global challenges, as stated in the prestigious international conferences and extensive courses by Romanian diplomats (Glavan and Shaun 2017), 2018 was a crucial year for defending Romania, as it had the potential to increase the country's military power and to strengthen its long-term security. 
It is remarked that the existing relationship between the military expenditures and the economic development in Romania can be evidenced by the modeling of the phenomena in the economic field and by testing the determinants for the development of the real sector, noting that the process of economic growth has become over time one of the most dynamic areas of economic studies.

We conclude that there will still be pressure on defense budgets of major players, as threats continue to increase, including cyber-attacks. The shift of economic power poles from the West to the East, demographic change and technological advancement are among the most important global trends that analysts believe they have a "profound effect" on defense and security.

Open Access This article is distributed under the terms of the Creative Commons Attribution 4.0 International License (http://creativecommons.org/licenses/by/4.0/), which permits unrestricted use, distribution, and reproduction in any medium, provided you give appropriate credit to the original author(s) and the source, provide a link to the Creative Commons license, and indicate if changes were made.

\section{References}

Alptekin, A., Levine, P.: Military expenditure and economic growth: a meta-analysis. Eur. J. Polit. Econ. 28(4), 636-650 (2012). https://doi.org/10.1016/j.ejpoleco.2012.07.002

Awawor, S., Yew, S.L.: The effect of military expenditure on growth: an empirical synthesis. Monash University, Department of Economics, ISSN 1441-5429, P25/14 (2014)

Barro, R., Sala-i-Martin, X.: Economic Growth. McGraw-Hill, New York (1995). ISBN 0-262-02553-1

Brasoveanu, L.O., Brasoveanu, I.: Efecte Ale Cheltuielilor Bugetare Asupra Creşterii Economice, Lucrările Colocviului Financiar-Monetar, Finanţele şi dezvoltarea durabilă. Editura ASE, Bucureşti (2007)

Chang, H.-C., Huang, B.-N., Yang, C.W.: Military expenditure and economic growth across different groups: a dynamic panel granger-causality approach. Econ. Model. 28(6), 2416-2423 (2011). https:// doi.org/10.1016/j.econmod.2011.06.001

Chang, T., Lee, C.-C., Hung, K., Lee, K.-H.: Does military spending really matter for economic growth in China and G7 countries: the roles of dependency and heterogeneity. Def. Peace Econ. 25(2), 177-191 (2014). https://doi.org/10.1080/10242694.2013.763460

Cappelen, A., Gleditsch, N.P., Bjerkholt, O.: Military spending and economic growth in the OECD countries. J. Peace Res. 21(4), 361-373 (1984)

Drăghici, M.: http://www.mediafax.ro/stirile-zilei/polonia-va-cere-efective-militare-nato-permanente-siarmament-suplimentar-de-teama-rusiei-15185761 (2016)

Economica.net: [Online]. http://www.economica.net/romania-pe-primul-loc-in-europa-de-est-la-crestereabugetului-de-aparare-in-2017_136108. Accessed 2017

Eurostat: [Online]. http://cursdeguvernare.ro/cheltuielile-militare-ale-romaniei-in-noul-context-al-nato-seva-cauta-inca-un-miliard-de-euro-prin-bugetul-public.html (2017)

Granger, C.W.J.: Investigating causal relations by econometric models and cross-spectral methods. Econometrica 37(3), 424-438 (1969). https://doi.org/10.2307/1912791

Glavan, S., Shaun, R.: Business Diplomacy Conference 2017 I Centrul de Strategii applicate. [online]. https ://www.strategiiaplicate.ro/2017/10/06/business-diplomacy-conference-2017 (2017)

Huang, J.-T., Kao, A.-P.: Does defence spending matter to employment in Taiwan. Def. Peace Econ. 16(2), 101-115 (2005). https://doi.org/10.1080/10242690500070094

Huntington, S.P.: Ciocnirea civilizaţiilor şi refacerea ordinii mondiale, Editura Antet, Bucureşti (2007)

Jingxi, M., Yiwen, J., Xiaoyong, X.: The relationship between military expenditures and economic growtha case study of the USA, Russia, Japan, Indian and China, 20 Air Force Academy, No 2 (29) (2015)

Khalid, M.A., Jabar, M.A., Razaq, A.: Military spending and economic growth: evidence from the US economy. Res. J. Finance Account. 6(7), 183-190 (2015)

Korkmaz, S.: The effect of military spending on economic growth and unemployment in Mediterranean countries. Int. J. Econ. Financ. Issues 5(2), 273-280 (2015) 
Pan, C.-I., Chang, T., Wolde-Rufael, Y.: Military spending and economic growth in the Middle East Countries: bootstrap panel causality test. Def. Peace Econ. (2014). https://doi.org/10.1080/10242 694.2014.891356

Pradhan, R.P., Arvin, M.B., Norman, N.R., Bhinder, H.K.: Military expenditure and economic growth: using causality, cointegration and missing variables. Int. J. Comput. Econ. Econom. 3(3-4), 164-186 (2013). https://doi.org/10.1504/IJCEE.2013.058496

Rota, M.: Military spending, fiscal capacity and the democracy puzzle. Explor. Econ. Hist. 60, 41-51 (2015). https://doi.org/10.1016/j.eeh.2015.11.002

Su, C., Xu, Y., Chang, H.L., Lobont, O.R., Liu, Z.: Dynamic causalities between defense expenditure and economic growth in China: evidence from rolling Granger causality test. Def. Peace Econ. (2018). https://doi.org/10.1080/10242694.2018.1505583

The Government of Romania: The Country Defense Strategy Guide for the period 2015-2019. [online]. http://www.presidency.ro/ro/presa/securitate-nationala-si-aparare/ghidul-strategiei-nationale-de-apara re-a-tarii-pentru-perioada-2015-2019

Wijeweera, A., Webb, M.J.: Military spending and economic growth in South Asia: a panel data analysis. Def. Peace Econ. 22(5), 545-554 (2011). https://doi.org/10.1080/10242694.2010.533905

Yakovlev, P.: Arms trade, military spending, and economic growth. Def. Peace Econ. 18(4), 317-338 (2007). https://doi.org/10.1080/10242690601099679

Publisher's Note Springer Nature remains neutral with regard to jurisdictional claims in published maps and institutional affiliations. 